\title{
Pengaruh Motivasi dan Dukungan Keluarga terhadap Prestasi Belajar Mahasiswa Selama Penggunaan E-Learning Masa Pandemi Covid 19 (Studi Kasus pada Mahasiswa Fakultas Ekonomi dan Bisnis Universitas Bumigora)
}

\author{
Isra Dewi Kuntary Ibrahim \\ israibrahim@universitasbumigora.ac.id \\ Universitas Bumigora \\ Irwan Cahyadi \\ Irwancahyadi@universitasbumigora.ac.id \\ Universitas Bumigora \\ Rini Anggriani \\ rinianggriani@universitasbumigora.ac.id \\ Universitas Bumigora \\ Abdurrahman \\ Abdurrahman@universitasbumigora.ac.id \\ Universitas Bumigora
}

\begin{abstract}
Abstrak
Penelitian ini bertujuan untuk melihat pengaruh secara signifikan Motivasi Dan Dukungan Keluarga Terhadap Prestasi Belajar Mahasiswa Selama Penggunaan E-Learning Masa Pandemi Covid 19. Jenis data dalam penelitian ini adalah data kualitatif. Pengumpulan data menggunakan sensus dengan jumlah responden 114 orang. Analisis dan pengujian hipotesis menggunakan Partial Least Square (PLS) dengan instrument penelitian menggunakan kuesioner online. Hasil penelitian menunjukkan bahwa terdapat pengaruh positif dan signifikan job insecurity terhadap turnover intentions dan terdapat pengaruh positif dan signifikan motivasi dan dukungan keluarga terhadap prestasi belajar mahasiswa selama penggunaan e-learning masa pandemic covid-19.
\end{abstract}

Kata kunci: motivasi, dukungan keluarga, prestasi belajar, e-learning, covid-19, partial least square.

\section{Pendahuluan}

Pandemi Covid-19 adalah krisis kesehatan yang pertama dan menjadi fokus di seluruh dunia.Pada awal bulan Januari 2020, korona atau yang dikenal dengan Covid-19 ini mulai menjadi topik terhangat yang dibicarakan oleh dunia. Indonesia sendiri melalui Presiden Republik Indonesia Bapak Joko Widodo bersama Menteri Kesehatan, Terawan Agus Putranto pada Senin tanggal 2 Maret 2020 mengumumkan bahwa Covid-19 sudah masuk ke Indonesia, sehingga siap atau tidak Indonesia harus menghadapi, mencegah, dan melawan penyebaran Covid-19 tersebut. Untuk itu Pemerintah telah melakukan berbagai upaya dan kebijakan, salah satunya adalah bekerja dari rumah atau Work From Home (WFH) bagi Aparatur Sipil Negara (ASN), yaitu melaksanakan tugas kedinasan di rumah/tempat tinggalnya masing-masing untuk mencegah dan meminimalisir penyebaran virus corona di masyarakat. Seperti halnya juga banyak Negara lainnya yang memutuskan untuk menutup sekolah, perguruan tinggi, universitas dan kantor-kantor pemerintahan serta perusahaan swasta juga memberlakukan bekerja dari rumah.

Provinsi Nusa Tenggara Barat sendiri merupakan Provinsi yang juga terdampak covid 19 atau virus korona ini.Dalam artikel CNN Indonesia, Gubernur Nusa Tenggara BaratZulkieflimansyah mengumumkan satu warganya positif terpapar virus korona (Covid19).Sehingga pada akhirnya rata-rata seluruh universitas di Provinsi NTB memberlakukan pembelajaran melalui daring atau online learning demi mendukung kebijakan pemerintah 
tersebut diatas. Universitas Bumigora merupakan salah satu universitas swasta yang dikenal sejak dulu menghasilkan lulusan terbaik di bidang Teknik Informastika yang menjunjung tinggi nilai Ilmu Pengetahuan dan Teknologi (IPTEK). Universitas Bumigora atau yang dikenal dengan sebutan UBG ini beralamat di Jalan Ismail Marzuki No.22 Cakranegara dan dalam hal ini sudah sangat sigap dalam menanggapi kebijakan pemerintah tersebut. Demi mendukung kebijakan work from home, social distancing dan physical distancing Universitas Bumigora telah menyediakan platform pengajaran online yang disebut E-Learning untuk mendukung proses belajar mengajar (PBM) selama semester Genap 2019/2020 ini secara online. Mahasiswa, dosen dan seluruh civitas akademika dapat mengaksesnya dari rumah dan tidak menggangu jadwal perkuliahan.

E-Learning Universitas Bumigora dikelola secara internal dan mandiri oleh tim ahli dan platform ini sudah ada sejak lama dan digunakan untuk kepentingan pengajaran online di lingkungan civitas akademika UBG demi mendukung perkuliahan. Selain menerapkan pembelajaran face to face atau tatap muka di kelas, dosen juga dapat memanfaatkan e-learning tersebut untuk melakukan pengajaran, pemberian kuis, pemberian tugas, maupun diskusi secara online. Saat kondisi pandemic covid 19 ini, e-learning Universitas Bumigora yang selama ini hanya dipakai sekitar 2-3 pertemuan saja dari sekian banyak pertemuan perkuliahan, sangat bermanfaat untuk dijadikan sumber pembelajaran utama bagi dosen untuk tetap menjalankan kewajiban mengajar dan mahasiswa untuk mendapatkan hak atas pengajaran tersebut. Tujuan pembelajaran yaitu agar mahasiswa mencapai prestasi belajar yang tinggi.Prestasi belajar merupakan tingkat kemanusiaan yang dimiliki mahasiswa dalam menerima, menolak, dan menilai informasi-informasi yang diperoleh dalam proses belajar mengajar.

Dalam artikel (Safitri and Yuniwati 2016), prestasi belajar siswa dipengaruhi oleh dua faktor utama yaitu faktor internal adalah faktor yang timbul dari dalam diri individu itu sendiri, diantaranya adalah minat, bakat, motivasi dan tingkat intelegensi. Faktor yang kedua yaitu faktor eksternal adalah segala bentuk pengaruh yang datang dari luar diri dan mempengaruhi kegiatan belajar seseorang, diantaranya adalah keluarga, sekolah dan faktor sosial.(Robbins and Judge 2008) menjelaskan bahwa motivasi merupakan proses yang menjelaskan intensitas, arah dan ketekunan usaha untuk mencapai suatu tujuan. Motivasi merupakan dorongan atau penggerak dasar bagi suatu keinginan, harapan dan tujuan yang dimiliki individu. Sumber motivasi bisa dari dalam diri sendiri tanpa adanya paksaan dari orang lain dan maupun berasal dari dorongan atau rangsangan dari orang lain. Apabila seseorang termotivasi untuk melakukan suatu kegiatan seperti belajar, maka dorongan tersebut akan mempengaruhi proses yang mengarah kepada tujuan yang ingin dicapai. Sebaliknya, apabila seseorang tidak termotivasi untuk melakukan suatu kegiatan, maka hal tersebut juga mempengaruhi usaha ataupun proses pencapaian tujuan (Manurung 2017).

Sekolah, Guru, dan Orangtua harus memberikan dukungan sosial di rumah agar anakanak dapatnyaman dalam belajar. Komponen-komponen ini harus mendorong perubahan pemodelan di lingkungan rumahdan ini merupakan bagian penting dari program intervensi awal untuk meningkatkan pengasuhan anak dengan menilaikemungkinan dampak dorongan perubahankebijakan dalam lingkungan belajar di rumah (Pajarianto et al. 2020). Baik motivasi maupun dukungan dari keluarga dapat menjadi komponen pendorong prestasi mahasiswa yang dapat dilihat dari nilai IPK atau Indeks Prestasi Kumulatif. IPK memang bukan merupakan tolak ukur mutlak atas prestasi mahasiswa, namun IPK yang diperoleh mahasiswa selama kuliah biasanya menjadi acuan dalam mengukur prestasi mahasiswa. Hal ini dikarenakan IPK merupakan rata-rata nilai kumulatif yang diperoleh mahasiswa dan atau lulusan suatu program studi. Dengan kata lain, keberhasilan studi sering disamakan dengan nilai IPK yang tinggi.

Berdasarkan latar belakang tersebut diperlukan suatu kajian mengenai mengenai Pengaruh Motivasi dan Dukungan Keluarga Terhadap Prestasi Belajar Mahasiswa Selama Penggunaan E-Learning dan peneliti melakukan Studi Kasus Pada Mahasiswa Fakultas Ekonomi dan Bisnis Universitas Bumigora. Program studi Manajemen dan Akuntansi yang berada dalam naungan FEB merupakan prodi baru dengan mahasiswa angkatan pertama yang baru memasuki semester 2. Mahasiswa tersebut baru saja menjalani 1,5 semester selama kurang lebih 6 bulan dengan kondisi normal, mahasiswa sedang belajar beradaptasi peralihan menjadi siswa di 
sekolah menengah atas dan menjadi mahasiswa. Mahasiswa mulai mengenal lingkungan kampus dan metode yang digunakan selama perkuliahan yaitu blended learning baik face to face dan online learning tetapi akibat pandemic covid 19 ini situasinya berubah. Hal ini yang ingin dikaji oleh peneliti.Apakah mahasiswa mampu beradaptasi terhadap perubahan metode pembelajara tersebut dan adakah dampak dari motivasi dan dukungan keluarga dirumah dalam pencapaian prestasi belajar mahasiswa selama semester genap ini.

\section{Tinjauan Pustaka}

\subsection{Motivasi}

Menurut Guido, dkk. (2016) dalam (Nasution and Purba 2017) menjelaskan bahwa motivasi lebih dekat pada mau melaksanakan tugas untuk mencapai tujuan. Motivasi adalah kekuatan, baik dari dalam maupun luar yang mendorong seseorang untuk mencapai tujuan tertentu yang telah ditetapkan sebelumnya. Selain itu menurut (Robbins and Judge 2008) menjelaskan bahwa motivasi merupakan proses yang menjelaskan intensitas, arah dan ketekunan usaha untuk mencapai suatu tujuan. Motivasi merupakan dorongan atau penggerak dasar bagi suatu keinginan, harapan dan tujuan yang dimiliki individu. Motivasi dapat bersumber dari dalam diri sendiri tanpa adanya paksaan dari orang lain dan motivasi dapat bersumber dari dorongan atau rangsangan dari orang lain. Apabila seseorang termotivasi untuk melakukan suatu kegiatan seperti belajar, maka dorongan tersebut akan mempengaruhi proses yang mengarah kepada tujuan yang ingin dicapai. Sebaliknya, apabila seseorang tidak termotivasi untuk melakukan suatu kegiatan, maka hal tersebut juga mempengaruhi usaha ataupun proses pencapaian tujuan (Manurung 2017).

\subsection{Dukungan Keluarga}

Untuk meningkatkan hasil belajar siswa, harus ada dorongan atau dukungan sosial yang baik dari siswa supaya siswa merasa diperhatikan oleh orang-orang terdekatnya, seperti dukungan keluarga/orang tua, guru, teman, dan pemerintah. Siswa akan termotivasi belajar jika keluarga/orang tua peduli dengan masalah yang dialami anak, serta memberikan arahanarahan atau jalan keluar dari permasalahan yang dialami anak, dengan perhatian serta kepedulian keluarga/orang tua kepada anak, maka anak bisa belajar dengan baik serta meningkatkan hasil belajar di sekolah. Perhatian dan pujian berprestasi akan memicu siswa akan belajar lebih baik lagi untuk mempertahankan serta meningkatkan hasil belajarnya. Kehadiran sumber-sumber dukungan sosial yang sesuai merupakan faktor utama bagi terbentuknya penyesuaian diri yang dapat meningkatkan rasa optimis (Alhafid and AN 2020).

Sekolah, Guru, dan Orangtua harus memberikan dukungan sosial di rumah agar anakanak dapat nyaman dalam belajar. Komponen-komponen ini harus mendorong perubahan pemodelan di lingkungan rumah dan ini merupakan bagian penting dari program intervensi awal untuk meningkatkan pengasuhan anak dengan menilai kemungkinan dampak dorongan perubahan kebijakan dalam lingkungan belajar di rumah (Pajarianto et al. 2020).

\subsection{Pengaruh Motivasi Terhadap Prestasi Belajar}

Hasil penelitian yang dilakukan oleh (Tokan and Imakulata 2019) menunjukkan bahwa motivasi intrinsik memiliki efek langsung pada perilaku belajar, dan itu keduanya secara langsung mempengaruhi prestasi belajar; motivasi intrinsik dan ekstrinsik dan perilaku belajar secara bersama-sama mempengaruhi pembelajaran pencapaian siswa. Penelitian lain yang mendukung adalah (Riswanto and Aryani 2017) meneliti hubungan antara faktor-faktor motivasi belajar siswa dan prestasi akademik yang diperoleh siswa. Kontribusi prestasi siswa didukung oleh motivasi siswa di sekolah. Namun beda halnya dengan hasil penelitian yang dilakukan oleh (Amro, Mundy, and Kupczynski 2018) yang menyatakan bahwa Motivasi dan Teknologi tidak signifikan, tetapi kepuasan terbukti penting dan signifikan dalam mempengaruhi prestasi mahasiswa dalam belajar. Maka dari itu dalam penelitian ini dihipotesiskan bahwa :

$\mathbf{H}_{\mathbf{1}}$ : Motivasi berpengaruh positif signifikan terhadap Prestasi Belajar Mahasiswa. 


\subsection{Pengaruh Dukungan Keluarga Terhadap Prestasi Belajar}

Berdasarkan hasil penelitian yang dilakukan oleh (Alhafid and AN 2020) Terdapat kontribusi yang signifikan antara dukungan orang tua dan peran teman sebaya terhadap hasil belajar sosiologi. Artinya atas adanya dukungan dari orang tua secara signifikan mempengaruhi hasil belajar siswa. Selain itu terdapat hasil penelitian yang mendukung hasil penelitian sebelumnya yang dilakukan oleh (Safitri and Yuniwati 2016) dengan hasil penelitian disimpulkan bahwa ada pengaruh yang signifikan antara motivasi dan dukungan keluarga terhadap prestasi belajar mahasiswa. Oleh karena itu, maka dalam penelitian ini dihipotesiskan bahwa :

H2 : Dukungan Keluarga berpengaruh positif signifikan terhadap Prestasi Belajar Mahasiswa.

\section{Kerangka Konseptual} terdahulu :

Berikut adalah kerangka konseptual penelitian berdasarkan teori dan penelitian

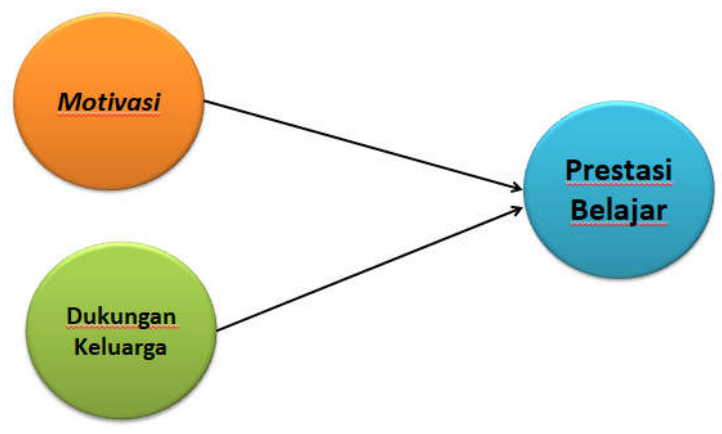

Gambar 1. Kerangka Konseptual Penelitian

\section{Metode Penelitian}

\subsection{Populasi dan Sampel Penelitian}

Dalam penelitian ini akan dapat menunjukkan Pengaruh Motivasi dan Dukungan Keluarga Terhadap Prestasi Belajar Mahasiswa Selama Penggunaan E-Learning Masa Pandemic Covid 19 (Studi Kasus Pada Mahasiswa Fakultas Ekonomi dan Bisnis Universitas Bumigora). Adapun populasi dalam penelitian merupakan seluruh mahasiswa pada Prodi Manajemen sejumlah 96 orang dan Prodi Akuntansi berjumlah 45 orang. Metode penentuan sampel adalah sensus yaitu semua populasi dijadikan sampel dalam penelitian. Dalam penelitian ini peneliti langsung mengumpulkan data dari unit sampling yang menjawab kuesioner melalui google form secara online dan tidak bertemu secara langsung dengan responden akibat dari kebijakan "social distancing" dari pemerintah dan WFH yang diberlakukan dengan total kuesioner yang terkumpul sejumlah 114 orang dari total 141 orang responden.

\subsection{Jenis dan Sumber Data}

Jenis data dalam penelitian ini adalah data kualitatif yaitu data yang tidak berbentuk angka namun berupa uraian atau penjelasan yang berhubungan dengan penelitian sehingga dapat ditarik kesimpulan yang dirubah menjadi data kuantitatif yaitu data yang berbentuk angka-angka dan secara langsung dapat di diukur. Sumber data yang digunakan dalam penelitian ini terdiri dari 2 sumber yaitu sebagai berikut Data Primer yaitu data yang diperoleh langsung dari responden yang menjadi subjek dalam penelitian. Data primer diperoleh dengan menyebarkan kuesioner secara online kepada seluruh mahasiswa pada Prodi Manajemen dan Akuntansi dan Data Sekunder yaitu data pendukung yang diperoleh dari tempat penelitian, jurnal, buku-buku literature dan dokumen lainnya yang ada hubungannya dengan masalah penelitian. Teknik pengumpulan data menggunakan wawancara online, teknik dokumentasi dan angket. Alat pengumpulan data dalam penelitian ini adalah teknik wawancara membutuhkan smartphone dan social media, teknik dokumentasi membutuhkan alat tulis dan buku tulis untuk 
pencatatan hasil wawancara dan pencatatan atas dokumen yang dimiliki obyek penelitian, teknik angket menggunakan kuesioner online sebagai alat pengumpulan data yang akan dikirimkan kepada responden untuk melihat Pengaruh Motivasi dan Dukungan Keluarga Terhadap Prestasi Belajar Mahasiswa Selama Penggunaan E-Learning Masa Pandemic Covid 19 (Studi Kasus Pada Mahasiswa Fakultas Ekonomi dan Bisnis Universitas Bumigora).

\subsection{Prosedur Analisa Data}

Dalam memberikan pembobotan pada masing-masing variabel digunakan skala lima tingkat yang terdiri dari sangat setuju, setuju, cukup, tidak setuju dan sangat tidak setuju. Darihasil perhitungan rata-rata jawaban responden, dapat dibuat skala distribusi kriteria sebagai berikut :

Tabel 1. Distribusi Interval Kelas Variabel Penelitian

\begin{tabular}{|c|c|c|c|}
\hline \multirow{2}{*}{ Interval } & \multicolumn{3}{|c|}{ Kategori/Pernyataan } \\
\cline { 2 - 4 } & Prestasi Belajar & Motivasi & $\begin{array}{c}\text { Dukungan } \\
\text { Keluarga }\end{array}$ \\
\hline $4,20-5,00$ & Sangat tinggi & Sangat tinggi & Sangat tinggi \\
\hline $3,39-4,19$ & Tinggi & Tinggi & Tinggi \\
\hline $2,58-3,38$ & Sedang & Sedang & Sedang \\
\hline $1,77-2,57$ & Rendah & Rendah & Rendah \\
\hline$\leq 1,76$ & Sangat rendah & Sangat rendah & Sangat rendah \\
\hline
\end{tabular}

Data Primer Diolah, 2020

Hasil uji reliabilitas instrumen penelitian semua item pada variabel penelitian dilihat dari nilai Cronbach's Alphanya di atas 0,6, sedangkan hasil uji validitas instrumen penelitian dengan menggunakan teknik korelasi Product Moment Pearson dimana semua item variabel penelitian yang digunakan standar nilainya lebih besar dari 0,3, sehingga semua item variable dapat dilanjutkan untuk dianalisa. Analisis data dalam penelitian ini menggunakan Partial Least Square. PLS adalah analisis persamaan structural (Stuktural Equation Model) berbasis varian yang secara simultan dapat melakukan pengujian model pengukuran sekaligus pengujian model structural. Model pengukuran digunakan untuk uji validitas dan reliabilitas, sedangkan model struktural digunakan untuk uji kausalitas (pengujian hipotesis dengan model prediksi).

Selanjutnya dilakukan pengujian hipotesis dengan menggunakan langkah-langkah sebagai berikut (Solimun and Rinaldo 2006) :

1) Analisis model, meliputi :

a. Uji Asumsi Linearitas, digunakan untuk mengetahui apakah model yang diperoleh telah tepat dalam menggambarkan hubungan antar variabel yang diteliti sehingga dikategorikan kedalam model yang baik atau fit. Dasar pengujian adalah dengan metode Curve Fit yang dihitung menggunakan software SPSS. Keputusan apakah hubungan antar variabel tersebut linear jika tingkat signifikansi lebih kecil dari 5\% $(\mathrm{p}<0,05)$.

b. Evaluasi Meausurement (Outer Model), outer model atau model pengukuran mendefinisikan bagaimana setiap blok indikator berhubungan dengan variabel latennya. Ada tiga kriteria untuk menilai outer model yaitu convergent validity, discriminant validity, dan composite reliability. Pada outer model dengan indikator refleksif seperti pada penelitian ini, dievaluasi dengan menggunakan convergent validity, discriminant validity dari indikatornya, dan composite reliability untuk blok indikator.

2) Evaluasi Model Struktural (Inner Model), penilaian terhadap model structural atau inner mmodel dilakukan untuk melihat hubungan antar konstruk, nilai signifikansi dan Rsquare model penelitian. Model structural dievaluasi menggunakan R-square untuk konstruk dependen, Stone Qeisser Q-Square test (Q2) untuk predictive relevance dan juga melihat besarnya koefisien jalur structural. Stabilitas dari estimasi ini dievaluasi dengan menggunakan uji t0 statistik yang didapat lewat prosedur bootstrapping. 
3) Pengujian hipotesis

Hartono dan Abdillah (2009:87) menjelaskan bahwa ukuran signifikansi keterdukungan hipotesis dapat digunakan perbandingan nilai t-table dan t-statistic. Hipotesis terdukung atau diterima apabila t-statistic lebih tinggi dibandingkan nilai t-table atau dapat juga dengan membandingkan p-value dengan nilai $\alpha$ yang dipergunakan. Nilai t-table untuk hipotesis satu ekor (one-tailed) dengan tingkat keyakinan 95 persen $(\alpha=0,05)$ adalah 1,680. Keterdukungan hipotesis dalam penelitian terjadi apabila nilai $t$-statistic $>1,680$ atau p-value $<\alpha=0,05$.

\section{Analisis Data dan Pembahasan}

\subsection{Analisis Data}

Analisis deskriptif didefinisikan menyampaikan deskripsi dan gambaran hasil data statistik tanpa maksud mengeneralisasikan kesimpulan. Analisis statistik deskriptif ditujukan untuk mendeskripsikan tanggapan responden terkait dengan pilihan pernyataan yang ditujukan oleh frekuensi jawaban responden. Untuk memberikan interpretasi persepsi responden terhadap variabel yang diteliti berdasarkan skor skalalikert.

\subsubsection{Variabel Motivasi Belajar}

Deskripsi jawaban responden variable motivasi belajar sebanyak 10 item.

Tabel 2. Distribusi Jawaban Responden Terhadap Motivasi Belajar

\begin{tabular}{|c|l|c|c|}
\hline No & \multicolumn{1}{|c|}{ Motivasi Belajar } & $\begin{array}{c}|c| \\
\text { Rata- } \\
\text { Rata }\end{array}$ & Kriteria \\
\hline 1 & $\begin{array}{l}\text { Selama semester 2 kuliah menggunakan e-learning, saya mengerjakan } \\
\text { tugas setiap MK yang diberikan oleh dosen walaupun tidak dibimbing } \\
\text { oleh orang lain yang lebih mampu }\end{array}$ & 3,78 & Tinggi \\
\hline 2 & $\begin{array}{l}\text { Walaupun kuliah menggunakan e-learning, saya semangat untuk } \\
\text { belajar demi keberhasilan di setiap MK semester 2 }\end{array}$ & 3,11 & Sedang \\
\hline 3 & $\begin{array}{l}\text { Saya selalu berusaha mendapatkan nilai yang setingi-tingginya } \\
\text { diantara teman-teman satu kelas selama semester 2 }\end{array}$ & 3,00 & Sedang \\
\hline 4 & $\begin{array}{l}\text { Saya selalu mentargetkan nilai ujian yanglebih baik dibandingkan } \\
\text { nilai ujian sebelumnya walaupun ujiannya secara online }\end{array}$ & 3,09 & Sedang \\
\hline 5 & $\begin{array}{l}\text { Ketika menjumpai soal/tugas yang sulit untuk dikerjakan saya } \\
\text { berusaha mencari jawaban di buku atau referensi-referensi sampai } \\
\text { menemukan jawabannya }\end{array}$ & 3,63 & Tinggi \\
\hline 6 & $\begin{array}{l}\text { Jika dari beberapa kali hasil ujian nilai yang sayaperoleh ternyata } \\
\text { kurang baik (belum mencapai KKM), saya tetap bersemangat dalam } \\
\text { belajar }\end{array}$ & 3,18 & Sedang \\
\hline 7 & $\begin{array}{l}\text { Saya sudah berusaha sebaik-baiknya dalam menghadapi } \\
\text { ujian setiap MK semester 2 agar mendapatkan nilai yang sangat baik }\end{array}$ & 3,03 & Sedang \\
\hline 8 & $\begin{array}{l}\text { Dalam mengerjakan tugas saya selalu berusaha } \\
\text { sebaik-baiknya menyelesaikan dengan tepat waktu }\end{array}$ & 3,02 & Sedang \\
\hline 9 & $\begin{array}{l}\text { Saat dirumah dan selesai jam pelajaran, saya selalu mengulang } \\
\text { menjawab latihan-latihan soal yang di kerjakan selama pembelajaran } \\
\text { yang saya anggap sulit }\end{array}$ & $\begin{array}{l}\text { Raya } \\
\text { permasalahan dalam tanya jawab kuis MK selama semester 2 }\end{array}$ & Tinggi \\
\hline 10 & \begin{tabular}{l} 
Saya selalu berusaha secara serius dalam menanggapi suatu \\
\hline
\end{tabular} & 3,44 & Tinggi \\
\hline
\end{tabular}

Tabel diatas merupakan jawaban responden terhadap 10 pernyataan mengenai motivasi belajar dengan rata-rata jawaban 3,30 dengan kriteria sedang, artinya mahasiswa fakultas ekonomi dan bisnis Universitas Bumigora merasa motivasi belajar mereka selama penggunaan e-learning pada masa pandemi covid-19 masuk kategori sedang. Namun untuk setiap item pertanyaan terlihat respon yang berbeda-beda, mahasiswa merasa selama semester 2 kuliah menggunakan e-learning, motivasi yang dirasakan tinggi untuk mengerjakan tugas setiap MK yang diberikan oleh dosen walaupun tidak dibimbing oleh orang lain yang lebih mampu, namun selama kuliah menggunakan e-learning semangat untuk belajar demi 
keberhasilan di setiap MK semester 2 mereka sedang tetapi mereka selalu berusaha mendapatkan nilai yang setingi-tingginya diantara teman-teman satu kelas selama semester 2 , mereka selalu mentargetkan nilai ujian yanglebih baik dibandingkan nilai ujian sebelumnya walaupun ujiannya secara online, Ketika menjumpai soal/tugas yang sulit untuk dikerjakan ada motivasi yang tinggi dalam diri mereka untuk berusaha mencari jawaban di buku atau referensi-referensi sampai menemukan jawabannya, jika dari beberapa kali hasil ujian nilai yang sayaperoleh ternyata kurang baik (belum mencapai KKM) adakalanya mereka bersemangat dan adakalanya tidak bersemangat dalam belajar, mahasiswa merasa sudah berusaha sebaikbaiknya dalam menghadapiujian setiap MK semester 2 agar mendapatkan nilai yang sangat baik, dalam mengerjakan tugas mahasiswa terkadang berusaha menyelesaikan dengan tepat waktu, saat dirumah dan selesai jam pelajaran mahasiswa motivasi mereka tinggi untukmengulang menjawab latihan-latihan soal yang di kerjakan selama pembelajaran yang di anggap sulit dan mahasiswa berusaha secara serius dalam menanggapi suatupermasalahan dalam tanya jawab kuis MK selama semester 2 dengan motivasi belajar yang tinggi.

\subsubsection{Varibel Dukungan Orang Tua}

Deskripsi jawaban responden variable motivasi belajar sebanyak 10 item.

Tabel 3. Distribusi Jawaban Responden Terhadap Dukungan Orang Tua

\begin{tabular}{|c|l|c|c|}
\hline No & \multicolumn{1}{|c|}{ Motivasi Belajar } & $\begin{array}{c}\text { Rata- } \\
\text { Rata }\end{array}$ & Kriteria \\
\hline $\mathbf{1}$ & $\begin{array}{l}\text { Keluarga mencari informasi tentang proses pembelajaran daring yang saya } \\
\text { lakukan }\end{array}$ & $\mathbf{3 , 3 9}$ & Tinggi \\
\hline $\mathbf{2}$ & $\begin{array}{l}\text { Keluarga mengajari saya tentang hal-hal yang harus dihindari selama } \\
\text { mengikuti perkuliah daring maupun luring }\end{array}$ & $\mathbf{3 . 6 1}$ & Tinggi \\
\hline $\mathbf{3}$ & $\begin{array}{l}\text { Keluarga memberikan nasehat ketika saya menghadapi masalah dalam } \\
\text { perkuliahan }\end{array}$ & $\mathbf{3 , 1 1}$ & Sedang \\
\hline $\mathbf{4}$ & $\begin{array}{l}\text { Keluarga mengingatkan saya untuk selalu mengikuti } \\
\text { Perkuliahan dengan rajin }\end{array}$ & $\mathbf{2 , 8 9}$ & Sedang \\
\hline $\mathbf{5}$ & $\begin{array}{l}\text { Selama masa pandemi covid-19, saya mendapat bimbingan/saran dari } \\
\text { keluarga dalam menjalani perkuliahan secara daring }\end{array}$ & $\mathbf{3 , 1 4}$ & Sedang \\
\hline $\mathbf{6}$ & $\begin{array}{l}\text { Keluarga memberikan pujianatau penghargaan positif ketika ada kemajuan } \\
\text { yang lebih baik dari diri saya }\end{array}$ & $\mathbf{3 , 3 4}$ & Sedang \\
\hline $\mathbf{7}$ & $\begin{array}{l}\text { Keluarga mendukung penuh tindakan yang dilakukan kampus dengan } \\
\text { perkuliahan daring di masa pandemic covid-19 ini }\end{array}$ & $\mathbf{2 , 9 5}$ & Sedang \\
\hline $\mathbf{8}$ & $\begin{array}{l}\text { Ketika saya kuliah daring dirumah, keluarga menganggap saya seperti } \\
\text { biasa, seperti sebelum saya belajar dari rumah yaitu tidak menjadi beban } \\
\text { dalamkeluarga }\end{array}$ & $\mathbf{3 , 2 5}$ & Sedang \\
\hline $\mathbf{9}$ & $\begin{array}{l}\text { Keluarga meyakinkan saya untuk patuh mengikuti program perkuliahan } \\
\text { yang diberikan kampus }\end{array}$ & $\mathbf{3 , 1 9}$ & Sedang \\
\hline $\mathbf{1 0}$ & $\begin{array}{l}\text { Keluarga memberikan motivasi kepada saya untuk selalu sabar } \\
\text { dan tabah dalam menghadapi masalah }\end{array}$ & $\mathbf{3 , 4 6}$ & Tinggi \\
\hline & $\begin{array}{l}\text { Rata-Rata } \\
\mathbf{3 n a}\end{array}$ & Sedang \\
\hline
\end{tabular}

Tabel diatas merupakan jawaban responden terhadap 10 pernyataan mengenai dukungan orang tuadengan rata-rata jawaban 3,23 dengan kriteria sedang demi mendukung prestasi belajar mahasiswa, artinya mahasiswa fakultas ekonomi dan bisnis Universitas Bumigora merasa dukungan orang tua selama penggunaan e-learning pada masa pandemi covid19 masuk kategori sedang. Namun untuk setiap item pertanyaan terlihat respon yang berbedabeda, keluarga mahasiswa dengan intensitas tinggi selalu mencari informasi tentang proses pembelajaran daring yang dilakukan mahasiswa selama pandemi, keluarga juga mengajari mahasiswa tentang hal-hal yang harus dihindari selama mengikuti perkuliah daring maupun luring, keluarga terkadang memberikan nasehat ketika saya menghadapi masalah dalam perkuliahan, keluarga terkadang mengingatkan saya untuk selalu mengikutiperkuliahan dengan rajin, selama masa pandemi covid-19, mahasiswa mendapat bimbingan/saran dari keluarga 
dalam menjalani perkuliahan secara daring, keluarga memberikan pujianatau penghargaan positif ketika ada kemajuan yang lebih baik dari diri mahasiswa, keluarga mendukung penuh tindakan yang dilakukan kampus dengan perkuliahan daring di masa pandemic covid-19 ini ketika kuliah daring dirumah, keluarga menganggap keberadaan mahasiswa seperti biasaseperti sebelum belajar dari rumah yaitu tidak menjadi beban dalamkeluarga, mahasiswa merasa keluarga selalu meyakinkan untuk patuh mengikuti program perkuliahan yang diberikan kampus, keluarga memberikan motivasi yang tinggi kepada mahasiswa untuk selalu sabardan tabah dalam menghadapi masalah.

\subsubsection{Evaluasi Measurement (outer model)}

1) Uji Validitas Konvergen

Berdasarkan hasil olah data menggunakan PLS, nilaiouter loadings dapat dilihat dibawah ini :

Tabel 4. Nilai Outer Loading

\begin{tabular}{|c|c|c|c|}
\hline & Dukungan Orang Tua & Motivasi Belajar & Prestasi Belajar \\
\hline IPK & & & 1.000000 \\
\hline X1 01 & & 0.865407 & \\
\hline X1 02 & & 0.801764 & \\
\hline X1 03 & & 0.783340 & \\
\hline X1 04 & & 0.439964 & \\
\hline X1 05 & & 0.825533 & \\
\hline X1 06 & & 0.802335 & \\
\hline X1 07 & & 0.881481 & \\
\hline X1 08 & & 0.399620 & \\
\hline X1 09 & & 0.828984 & \\
\hline X1 10 & & 0.790773 & \\
\hline X2 01 & 0.373516 & & \\
\hline X2 02 & 0.780086 & & \\
\hline X2 03 & 0.807510 & & \\
\hline X2 04 & 0.699628 & & \\
\hline X2 05 & 0.813242 & & \\
\hline X2 06 & 0.901039 & & \\
\hline X2 07 & 0.688431 & & \\
\hline X2 08 & 0.581779 & & \\
\hline X2 09 & 0.823756 & & \\
\hline X2 10 & 0.859066 & & \\
\hline & & & \\
\hline
\end{tabular}

Sumber : Data Primer Diolah

Tabel di atas menunjukkan bahwa semua indikator baik dari variabel Motivasi Belajar, Dukungan Orang Tua dan Prestasi Belajar memiliki nilai outer loadings di atas 0,3 sehingga semua indikator diikutsertakan dalam pengolahan dataselanjutnya.

2) Uji Validitas Diskriminan

Nilai AVE yang didapatkan dengan olah data menggunakan PLS, sebagai berikut : 
Tabel 5. Tabel Nilai Square Root of Average Variance Extract (AVE) Variabel Laten

\begin{tabular}{|c|c|c|c|}
\hline Variabel & AVE & $\sqrt{\text { AVE }}$ & Keterangan \\
\hline Motivasi Belajar & 0,559 & 0,748 & Valid \\
\hline Dukungan Orang Tua & 0,577 & 0,760 & Valid \\
\hline Prestasi Belajar & 1,000 & 1 & Valid \\
\hline
\end{tabular}

Sumber : Data Primer Diolah, 2020

Tabel diatas menunjukkan nilai akar AVE masing-masing lebih besar dari 0,5 sehingga dapat disimpulkan bahwa variabel yang digunakan pada penelitian adalah valid. Seluruh variabel yang dianalisis lebih besar dari nilai korelasi tertinggi antar masing-masing variabel independen dengan variabel lainnya.

3) Reliabilitas Komposit

Nilai composite reliability di atas 0,70 dapat dikatakan bahwa variable dalam penelitian ini memiliki reliabilitas tinggi. Pada tabel akan disajikan nilai composite reliability:

Tabel 6. Nilai Composite Reliability

\begin{tabular}{|c|c|}
\hline Variabel & Composite Reliability \\
\hline Motivasi Belajar & 0,924 \\
\hline Dukungan Orang Tua & 0,929 \\
\hline Prestasi Belajar & 1,000 \\
\hline
\end{tabular}

Sumber : Data Primer Diolah, 2020

Nilai reliabilitas komposit yang ditunjukkan pada tabel di atas untuk setiap konstruk Motivasi Belajar, Dukungan Orang Tua dan Prestasi Belajar menunjukkan bahwa konstruk adalah reliabel.

Berdasarkan hasil evaluasi secara keseluruhan, baik convergent dan discriminant validity dan composite reliability yang telah dipaparkan di atas, maka dapat disimpulkan bahwa indikator-indikator sebagai pengukur variabel laten merupakan pengukur yang valid dan reliabel.

4) Evaluasi Model Struktural (Inner Model)

Penilaian terhadap model structural atau inner model dilakukan untuk melihat hubungan antar konstruk, nilai signifikansi dan R-Square model penelitian. Berikut gambar yang menunjukkan nilai tersebut :

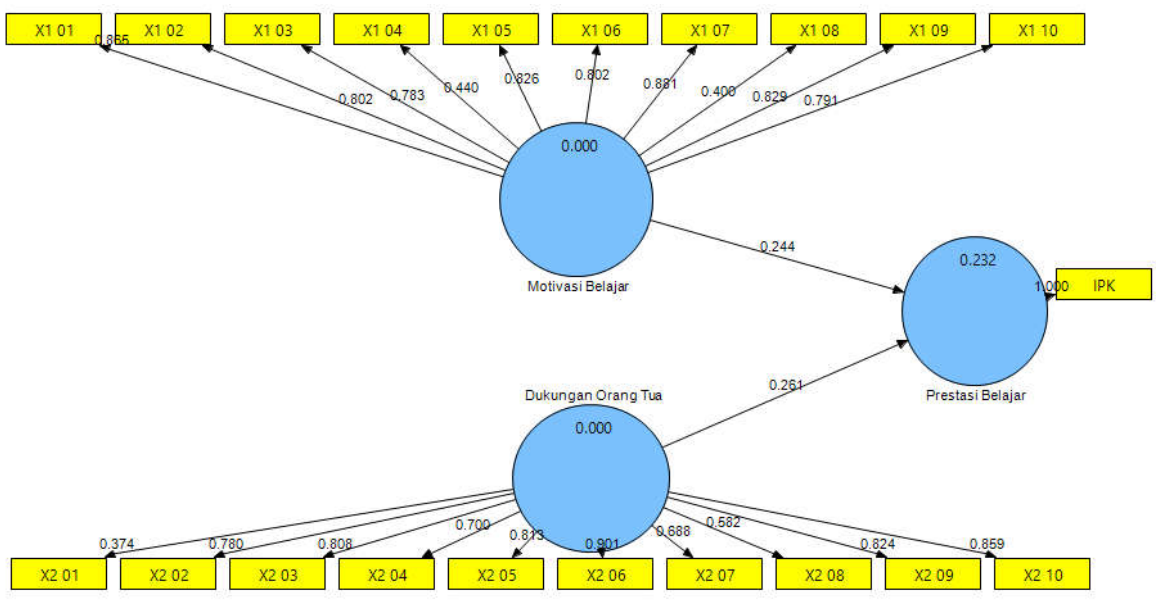

Gambar 2. Model Struktural Prestasi Akademik, Motivasi dan Perilaku Belajar Sumber : Data Primer Diolah 
Dari gambar diatas dapat dijelaskan bahwa covariance pengukuran indikator dipengaruhi oleh konstruk laten atau mencerminkan variasi dari konstruk unidimensional yang digambarkan dengan bentuk lingkaran dengan beberapa anak panah dari konstruk ke indikator. Model ini menghipotesiskan bahwa perubahan pada konstruk laten mempengaruhi perubahan pada indikator. Dalam model tersebut terdapat dua variabel eksogen yaitu motivasi belajar dan dukungan orang tua serta satu variabel endogen yaitu Prestasi Belajar. Penilaian model dengan PLS dimulai dengan melihat R-square untuk setiap variabel laten dependen. Perubahan nilai R-square dapat digunakan untuk menilai pengaruh variabel laten eksogen tertentu terhadap variabel laten endogen yang mempunyai pengaruh substantif. Gambar 1. menunjukkan nilai R-square variabel Perilaku Belajar sebesar 0.204 dan Prestasi Akademik sebesar 0.867. Semakin tinggi nilai R-square, maka semakin besar kemampuan variabel eksogen tersebut dapat menjelaskan variabilitas variabel endogen, sehingga semakin baik persamaan struktural. Untuk variabel Motivasi Belajar dan Dukungan Orang Tua memiliki nilai R square sebesar 0.232 yang bermakna bahwa 23,2\% yang bermakna bahwa $86.7 \%$ variance prestasi belajar mampu dijelaskan oleh variabel Motivasi Belajar dan Dukungan Orang Tua secara bersama-sama sedangkan sisanya dijelaskan oleh variabel lain di luar model penelitian.

\subsection{Pengujian Hipotesis}

Signifikansi parameter yang diestimasi memberikan informasi yang sangat berguna mengenai hubungan antara variabel-variabel penelitian. Dasar yang digunakan dalam menguji hipotesis adalah nilai yang terdapat pada output result for inner weight. Tabel 5.2 memberikan output estimasi untuk pengujian model struktural.

Tabel 7. Nilai Hasil Uji Bootstrap Koefisien Jalur Konstruk Penelitian

\begin{tabular}{|c|c|c|c|c|c|}
\hline & $\begin{array}{c}\text { Original } \\
\text { Sample (0) }\end{array}$ & $\begin{array}{c}\text { Sample } \\
\text { Mean (M) }\end{array}$ & $\begin{array}{c}\text { Standard } \\
\text { Deviation } \\
\text { (STDEV) }\end{array}$ & $\begin{array}{c}\text { Standard } \\
\text { Error } \\
\text { (STERR) }\end{array}$ & $\begin{array}{c}\text { T Statistics } \\
(\mid \mathbf{O} / \text { STERR|) }\end{array}$ \\
\hline $\begin{array}{c}\text { Dukungan Orang Tua -> } \\
\text { Prestasi Belajar }\end{array}$ & 0.260866 & 0.290023 & 0.121474 & 0.121474 & 2.147505 \\
\hline $\begin{array}{c}\text { Motivasi Belajar }-> \\
\text { Prestasi Belajar }\end{array}$ & 0.243508 & 0.229455 & 0.133737 & 0.133737 & 1.820806 \\
\hline
\end{tabular}

Sumber : Data Primer Diolah

\subsubsection{Pengujian Hipotesis 1 : Pengaruh Motivasi Belajar Terhadap Prestasi Belajar}

Hipotesis 1 menyatakan bahwa Motivasi belajar berpengaruh positif signifikan terhadap Prestasi Belajar. Hasil uji terhadap koefisien parameter antara Motivasi belajar terhadap Prestasi Belajar menunjukkan adanya pengaruh positif dengan nilai koefisien 0,244 dengan nilai t statistic sebesar 1,821 menunjukkan pengaruhnya signifikan. Nilai t statistic tersebut berada diatas nilai kritis 1,680, dengan demikian H1 diterima. Hal ini menunjukkan bahwa Motivasi Belajar berpengaruh positif signifikan terhadap Prestasi Belajar.

Artinya jika motivasi belajar seorang mahasiswa tinggi maka akan tinggi pula prestasi belajar yang didapatkan oleh mahasiswa tersebut yang akan terlihat dari nilai IPK yang didapatkannya begitupun sebaliknya. 
Tabel 8. Skor Variabel Motivasi Belajar

\begin{tabular}{|c|c|c|c|c|}
\hline Variabel & Kategori Variabel & $\begin{array}{c}\text { Rentang } \\
\text { Skor }\end{array}$ & $\begin{array}{c}\text { Jumlah } \\
\text { Responden } \\
\text { (orang) }\end{array}$ & $\%$ \\
\hline \multirow{6}{*}{ Motivasi } & Sangat Tinggi & 50 & $\mathbf{0}$ & $\mathbf{0 \%}$ \\
\hline & Tinggi & $37-49$ & 43 & $38 \%$ \\
\hline & Sedang & $24-36$ & 68 & $60 \%$ \\
\hline & Rendah & $11-23$ & 3 & $3 \%$ \\
\hline & Sangat Rendah & 10 & $\mathbf{0}$ & 0\% \\
\hline & \multicolumn{2}{|l|}{ Total } & 114 & $100 \%$ \\
\hline
\end{tabular}

Sumber : Data Primer Diolah

Lebih rinci dijelaskan pada tabel diatas bahwa dari jawaban responden terhadap 10 pernyataan mengenai motivasi belajar terdapat 60\% mahasiswa fakultas ekonomi dan bisnis Universitas Bumigora merasa motivasi belajar mereka selama penggunaan e-learning pada masa pandemi covid-19 masuk kategori sedang. Mahasiswa tidak merasakan motivasi yang terlalu tinggi dan terlalu rendah namun motivasi yang dirasakan adalah sedang. Mereka merasa selama semester 2 kuliah menggunakan e-learning, motivasi yang dirasakan sedang untuk mengerjakan tugas setiap MK yang diberikan oleh dosen walaupun tidak dibimbing oleh orang lain yang lebih mampu, walaupun kuliah menggunakan e-learning semangat untuk belajar demi keberhasilan di setiap MK semester 2 mereka sedang tetapi mereka selalu berusaha mendapatkan nilai yang setingi-tingginya diantara teman-teman satu kelas selama semester 2, mereka selalu mentargetkan nilai ujian yanglebih baik dibandingkan nilai ujian sebelumnya walaupun ujiannya secara online, Ketika menjumpai soal/tugas yang sulit untuk dikerjakan ada motivasi dalam diri mereka untuk berusaha mencari jawaban di buku atau referensi-referensi sampai menemukan jawabannya, jika dari beberapa kali hasil ujian nilai yang sayaperoleh ternyata kurang baik (belum mencapai KKM) adakalanya mereka bersemangat dan adakalanya tidak bersemangat dalam belajar, mahasiswa merasa sudah berusaha sebaik-baiknya dalam menghadapiujian setiap MK semester 2 agar mendapatkan nilai yang sangat baik, dalam mengerjakan tugas mahasiswa terkadang berusaha menyelesaikan dengan tepat waktu, saat dirumah dan selesai jam pelajaran mahasiswa terkadang mengulang menjawab latihan-latihan soal yang di kerjakan selama pembelajaran yang di anggap sulit, mereka terkadang berusaha secara serius dalam menanggapi suatupermasalahan dalam tanya jawab kuis MK selama semester 2 .

\subsubsection{Pengujian Hipotesis 2 : Pengaruh Dukungan Orang Tua Terhadap Prestasi Belajar}

Hipotesis 2 menyatakan bahwa Dukungan Orang Tua berpengaruh positif signifikan terhadap Prestasi Belajar. Hasil uji terhadap koefisien parameterantara Dukungan Orang Tua terhadap Prestasi Belajar menunjukkan adanya pengaruh positif dengan nilai koefisien 0,261 dan nilai t statistic sebesar 2,148 menunjukkan pengaruhnya signifikan. Nilai t statistic tersebut berada di atas nilai kritis 1,680, dengan demikian H1 diterima. Hal ini menunjukkan bahwa Dukungan Orang Tua berpengaruh positif dan signifikan terhadap Prestasi Belajar.

Tabel 9. Skor Variabel Motivasi Belajar

\begin{tabular}{|c|c|c|c|c|}
\hline Variabel & $\begin{array}{c}\text { Kategori } \\
\text { Variabel }\end{array}$ & $\begin{array}{c}\text { Rentang } \\
\text { Skor }\end{array}$ & $\begin{array}{c}\text { Jumlah } \\
\text { Responden } \\
\text { (orang) }\end{array}$ & \% \\
\hline \multirow{4}{*}{$\begin{array}{c}\text { Dukungan } \\
\text { Keluarga }\end{array}$} & Sangat Tinggi & 50 & $\mathbf{0}$ & $\mathbf{0 \%}$ \\
\cline { 2 - 5 } & Tinggi & $37-49$ & $\mathbf{3 9}$ & $\mathbf{3 4 \%}$ \\
\cline { 2 - 5 } & Sedang & $24--36$ & $\mathbf{5 2}$ & $\mathbf{4 6 \%}$ \\
\cline { 2 - 5 } & Rendah & $11--23$ & $\mathbf{2 3}$ & $\mathbf{2 0 \%}$ \\
\cline { 2 - 5 } & Sangat Rendah & 10 & $\mathbf{0}$ & $\mathbf{0 \%}$ \\
\cline { 2 - 5 } & \multicolumn{2}{|c|}{ Total } & $\mathbf{1 1 4}$ & $\mathbf{1 0 0 \%}$ \\
\hline
\end{tabular}

Sumber : Data Primer Diolah 
Lebih rinci dijelaskan pada tabel diatas dari jawaban responden terhadap 10 pernyataan bahwa 46\% mahasiswa fakultas ekonomi dan bisnis Universitas Bumigora merasa dukungan keluarga yang mereka rasakan selama penggunaan e-learning pada masa pandemi covid-19 masuk kategori sedang. Mahasiswa tidak merasakan motivasi yang terlalu tinggi dan terlalu rendah namun dukungan keluarga yang dirasakan adalah sedang. Selama penggunaan elearning pada masa pandemi covid-19 mahasiswa merasa intensitas keluargamencari informasi tentang proses pembelajaran daring yang mahasiswa lakukan masuk kategori sedang, keluarga mengajari saya tentang hal-hal yang harus dihindari selama mengikuti perkuliah daring maupun luring, keluarga memberikan nasehat ketika mahasiswa menghadapi masalah dalam perkuliahan, keluarga mengingatkan untuk selalu mengikuti perkuliahan dengan rajin, selama masa pandemi covid-19, mahasiswa merasa mendapat bimbingan/saran dari keluarga dalam menjalani perkuliahan secara daring, keluarga memberikan pujianatau penghargaan positif ketika ada kemajuan yang lebih baik dari diri mereka, keluarga mendukung penuh tindakan yangdilakukan kampus dengan perkuliahan daring di masa pandemic covid-19 ini ketika mahasiswa kuliah daring dirumah, keluarga menganggap mahasiswa seperti biasa, seperti sebelum mereka belajar dari rumah yaitu tidak menjadi beban dalamkeluarga, keluarga meyakinkan mahasiswa untuk patuh mengikuti program perkuliahan yang diberikan kampus, keluarga memberikan motivasi kepada mahasiswa untuk selalu sabardan tabah dalam menghadapi masalah.

\section{Kesimpulan dan Rekomendasi \\ 6.1. Kesimpulan}

Motivasi belajar berpengaruh positif signifikan terhadap Prestasi Belajar dan Dukungan orang tua juga berpengaruh positif dan signifikan terhadap prestasi belajar mahasiswa Fakultas Ekonomi dan Bisnis Universitas Bumigora selama penggunaan e-learning pada masa pandemi covid-19

\subsection{Rekomendasi}

Saran untuk Pihak Manajemen Universitas Bumigora secara umum dan pihak Prodi serta seluruh civitas akademika Manajemen dan Akuntansi Fakultas Ekonomi dan Bisnis mengusahakan pembelajaran yang menarik selama keberlanjutan penggunaan e-learning untuk pembelajaran masa pandemic covid-19 ini. Akibat keterbatasan kegiatan tatap muka, para pengajar harus lebih memotivasi mahasiswa untuk berinisiatif belajar secara mandiri dan aktif mencari tahu dan bertanya jika ada sesuatu dan lain hal yang tidak dipahami, tidak membatasai ruang gerak mahasiswa untuk berkreativitas dengan cara aman sesuai dengan protocol covid19. Serta untuk orang tua wali mahasiswa juga mengambil peran serta untuk memotivasi dan memberikan dukungan baik moril maupun materil untuk kelancaran pembelajaran daring ini.

Untuk peneliti selanjutnya mungkin dapat membandingkan prestasi belajar mahasiswa pasca covid-19.

\section{Daftar Pustaka}

Alhafid, Arif Fayyat and Desri Nora AN. 2020. "Kontribusi Dukungan Sosial Orang Tua Dan Peran Teman Sebaya Terhadap Hasil Belajar Sosiologi Siswa Kelas X Dan XI Di SMA Negeri 2 Bengkulu Selatan." 1(4):284-300.

Amro, Hanan Jamal, Marie-Anne Mundy, and Lori Kupczynski. 2018. "The Effects of Motivation , Technology and Satisfaction on Student Achievement in Face-to-Face and Online College Algebra Classes." 2(1).

Manurung, Tarida Marlin Surya. 2017. "Pengaruh Motivasi Dan Perilaku Belajar Terhadap Prestasi Akademik Mahasiswa." 1(1):17-26.

Nasution, Siti Zahara and Widya Darayani Purba. 2017. "Pengaruh Dukungan Keluarga Terhadap Motivasi Mahasiswa Reguler Menjalani Pendidikan Di Fakultas Keperawatan Universitas Sumatera Utara." 
Pajarianto, Hadi, Abdul Kadir, Nursaqinah Galugu, Puspa Sari, and Sofia Februanti. 2020. "Study from Home in the Middle of the COVID-19 Pandemic : Analysis of Religiosity , Teacher , and Parents Support Against Academic Stress." 12(2):1791-1807.

Riswanto, Ari and Sri Aryani. 2017. "Learning Motivation and Student Achievement: Description Analysis and Relationships Both."COUNS-EDU: The International Journal of Counseling and Education 2(1): 42.

Robbins, Stephen P. and Timothy A. Judge. 2008. Perilaku Organisasi Edisi Ke-12. Jakarta: Salemba Empat.

Safitri, Faradilla and Cut Yuniwati. 2016. "Pengaruh Motivasi Dan Dukungan Keluarga Terhadap Prestasi Belajar Mahasiswa Tingkat II Prodi D-III Kebidanan Universitas Ubudiyah Indonesia The Effect of Motivation and Family Support on Learning Achievement of D-III Product Level II Students of Ubudiyah ." 2(2):154-61.

Solimun, Nurjannah and Adji Ahmad Rinaldo. 2006. "Pemodelan Persamaan Struktural: Pendekatan PLS Dan SEM." Modul Pelatihan Aplikasi Software Smart PLS Dan AMOS, Fakultas MIPA Dan Program Pascasarjana, Universitas Brawijaya Malang.

Tokan, Moses Kopong and Mbing Maria Imakulata. 2019. "The Effect of Motivation and Learning Behaviour on Student Achievement." 39(1):1-8. 
